Saefas, S.A. · S. Rosniawaty $\cdot$ Y. Maxiselly

\title{
Pengaruh konsentrasi zat pengatur tumbuh alami dan sintetik terhadap pertumbuhan tanaman teh (Camellia sinensis (L.) O. Kuntze) klon GMB 7 setelah centering
}

\author{
The effect of natural and synthetic plant growth regulator \\ concentration on growth of tea plants (Camellia sinensis (L.) $\mathrm{O}$. \\ Kuntze) clone GMB 7 after centering
}

Diterima : 17 Agustus 2017/Disetujui : 25 Agustus 2017 / Dipublikasikan : 31 Agustus 2017

CDepartment of Crop Science, Padjadjaran University

\begin{abstract}
Tea is perennial plants and their shoots as its harvesting target. Centering and application of cytokinins as Plant Growth Regulator (PGR) on tea immature plants can increase the growth of tea plant. This research aimed to find out concentration of natural and synthetic plant growth regulator on growth of tea plants clone GMB 7 after centering. This research was conducted from December 2016March 2017 at Ciparanje field station, Faculty of Agriculture, Padjadjaran University, Jatinangor, Sumedang Regency, West Java. This study verified several concentrations of growth regulators (PGR) of cytokinins, i.e coconut water as natural PGR at concentrations of $25 \%, 50 \%$, $75 \%$ and Benzyl Amino Purine (BAP) as synthetic PGR at concentrations of $60 \mathrm{ppm}, 90$ ppm and $120 \mathrm{ppm}$ on vegetative components of GMB 7 tea clone plant. The experimental design used Randomized Block Design (RBD) comprised of 7 treatments with 4 replications. The results showed that the application of BAP with concentration of 60, 90, and $120 \mathrm{ppm}$ showed the best result in increasing number of leaves at 4 Weeks After Application, while BAP with concentration of 60 and $120 \mathrm{ppm}$ presented the as the best treatment in increasing number of buds at 4, 6, 10, and 12 Weeks After Application.
\end{abstract}

Keywords: Centering - Cytokinins - Coconut water - Benzyl Amino Purine

\footnotetext{
Dikomunikasikan oleh Intan Ratna Dewi Anjarsari

Saefas, S.A., S. Rosniawaty, dan Y. Maxiselly

Jurusan Agroteknologi Departemen BudidayaTanaman

Fakultas Pertanian Universitas Padjadjaran

Korespondensi: santi.rosniawaty@unpad.ac.id
}

Sari Tanaman teh merupakan tanaman tahunan yang memiliki organ target pucuk. Tanaman teh dapat ditingkatkan pertumbuhannya dengan pemeliharaan berupa centering dan pemberian zat pengatur tumbuh (ZPT) sitokinin pada fase TBM. Penelitian ini bertujuan untuk memperoleh konsentrasi zat pengatur tumbuh alami atau sintetik yang berpengaruh paling baik terhadap pertumbuhan tanaman teh klon GMB 7 setelah centering. Penelitian ini dilakukan pada bulan November 2016 sampai Maret 2017 di kebun percobaan Ciparanje, Fakultas Pertanian Universitas Padjadjaran, Jatinangor, Kabupaten Sumedang, Jawa Barat. Penelitian ini menguji beberapa konsentrasi zat pengatur tumbuh (ZPT) sitokinin, yaitu air kelapa sebagai ZPT alami pada konsentrasi 25\%, 50\%, 75\% dan Benzil Amino Purin (BAP) sebagai ZPT sintetik pada konsentrasi 60 ppm, 90 ppm dan 120 ppm yang diaplikasikan pada tanaman teh TBM klon GMB 7. Rancangan penelitian yang digunakan adalah Rancangan Acak Kelompok (RAK) terdiri dari 7 perlakuan yang diulang 4 kali. Hasil penelitian menunjukkan bahwa penggunaan zat pengatur tumbuh berupa BAP dengan konsentrasi 60 ppm, 90 ppm dan 120 ppm memberikan hasil terbaik dalam pertambahan jumlah daun (4 MSP), sementara BAP kosentrasi $60 \mathrm{ppm}$ dan $120 \mathrm{ppm}$ memberikan hasil positif terhadap pertambahan jumlah tunas $(4,6,10$ dan 12 MSP).

Kata kunci: Centering • Sitokinin • Air kelapa • Benzil Amino Purin 


\section{Pendahuluan}

Tanaman teh (Camellia sinensis (L.) O. Kuntze) merupakan salah satu komoditas perkebunan unggulan di Indonesia yang berasal dari daerah subtropis dan banyak diminati sebagai salah satu bahan baku produk penyegar. Penjualan hasil olahan tanaman ini mampu memberikan kontribusi yang cukup tinggi terhadap penambahan devisa negara dari sektor non migas. Menurut data Badan Pusat Statistik (2014), pada tahun 2013 nilai ekspor tanaman teh mencapai 157.498.000 USD. Hasil tersebut mengalami penurunan 710.000 USD dari tahun sebelumnya. Jumlah penurunan ini terjadi karena adanya hambatan agroindustri teh di Indonesia, salah satunya adalah rendahnya produktivitas tanaman (Sudjarmoko,2014).

Usaha untuk menanggulangi rendahnya produktivitas tanaman adalah dengan penggunaan bibit unggul untuk budidaya teh. Bibit unggul dapat dihasilkan dari perbanyakan secara vegetatif. Perbanyakan vegetatif sering dilakukan dengan bahan tanaman asal setek berupa klon (Setyamidjaja, 2010). Pusat Penelitian Teh dan Kina Gambung telah melepaskan beberapa klon unggul untuk bibit tanaman teh yaitu klon GMB 1, GMB 2, GMB 3, GMB 4, GMB 5, GMB 6, GMB 7, GMB 8, GMB 9, GMB 10, dan GMB 11. Berdasarkan seri klon tersebut, klon GMB 7 merupakan klon yang paling unggul karena potensi hasilnya tinggi sekitar $5800 \mathrm{~kg} / \mathrm{ha} /$ tahun (Direktorat Perbenihan Perkebunan, 2014).

Teknik budidaya pada fase Tanaman Belum Menghasilkan (TBM) ini sangat berpengaruh terhadap produktivitas tanaman teh pada fase Tanaman Menghasilkan (TM). Salah satu pemeliharaan tanaman teh untuk membentuk percabangan adalah centering yaitu pembentukan bidang petik dengan cara memotong batang tanaman teh hingga disisakan setinggi 20 cm (Syakir dkk., 2010). Teknik pemangkasan dapat memacu pertumbuhan cabang dan tunas sehingga akan terjadi peningkatan pertumbuhan pucuk tanaman teh.

Pembentukan cabang dan pertumbuhan tunas pada tanaman juga dipacu oleh hormon sitokinin yang berperan dalam aktivasi pembelahan sel (George et al., 2008). Hormon sitokinin merupakan senyawa turunan adenin yang berguna untuk merangsang terbentuknya tunas, berpengaruh dalam metabolisme sel dan merangsang sel dorman (Karjadi dan Buchory, 2008).

Seiring dengan kemajuan pengetahuan dan teknologi tentang biokimia, saat ini telah ditemukan beberapa senyawa yang memiliki fungsi fisiologis serupa dengan hormon tumbuhan. Sumber ZPT sitokinin alami pada tanaman teh adalah air kelapa. Selama ini air banyak dimanfaatkan untuk minuman kesegaran. Air kelapa mengandung berbagai macam zat, termasuk didalamnya hormon sitokinin dan auksin (Yong et al., 2009). Benzil Amino Purin (BAP) merupakan salah satu jenis zat pengatur tumbuh sintetik golongan sitokinin yang sering digunakan dalam pertumbuhan tanaman (George et al., 2008).

Respon positif tanaman terhadap aplikasi zat pengatur tumbuh dipengaruhi oleh beberapa faktor, diantaranya jenis tanaman, fase tumbuh tanaman, jenis zat pengatur tumbuh, konsentrasi dan cara aplikasi zat pengatur tumbuh (Fahmi, 2014). Adanya pengaruh konsentrasi menyebabkan zat pengatur tumbuh perlu ditentukan konsentrasinya saat melakukan aplikasi pada tanaman. Bedasarkan hal tersebut maka pada penelitian ini digunakan ZPT Benzil Amino Purin (BAP) dan air kelapa untuk mempercepat percabangan dan pertumbuhan tunas lateral pada tanaman teh klon GMB 7 setelah centering.

\section{Bahan dan Metode}

Percobaan dilakukan di Kebun Percobaan Ciparanje, Fakultas Pertanian, Universitas Padjajaran, Jatinangor, Sumedang Jawa Barat pada bulan Desember 2016 sampai Maret 2017. Bahan yang digunakan dalam percobaan ini adalah tanaman teh klon GMB 7 berumur 10 bulan, zat pengatur tumbuh BAP, air kelapa, alkohol 95\%, aquades, furadan, pupuk Urea, pupuk $\mathrm{KCl}$ dan pupuk SP-36, air, pestisida berbahan aktif profenofos.

Metode yang digunakan dalam percobaan ini adalah menggunakan metode eksperimen Rancangan Acak Kelompok (RAK) sederhana yang terdiri dari tujuh perlakuan dan diulang empat kali kali. Perlakuan yang diuji dalam percobaan ini adalah: A (Tanpa konsentrasi ZPT/Kontrol); B (Konsentrasi air kelapa 25\%); C (Konsentrasi air kelapa 50\%); D (Konsentrasi air kelapa 75\%); E (Konsentrasi BAP 60 ppm); (Konsentrasi BAP 90 ppm); (Konsentrasi BAP 90 ppm). Data yang diperoleh diuji normalitas 
Kolmogorov Smirnov. Apabila data yang dihasilkan normal, maka akan dilanjutkan dengan analisis ragam dengan uji $\mathrm{F}$ (Fisher) pada taraf 5\%. Uji lanjut Duncan pada taraf 5\% dilakukan apabila terdapat perbedaan antar perlakuan.

Centering dilakukan dua minggu sebelum aplikasi ZPT pertama. Praktiknya dengan memotong batang utama menggunakan gunting setek dan disisakan 5 helai daun pada tanaman teh. Aplikasi BAP dan air kelapa dilakukan dengan cara disemprotkan ke seluruh bagian tajuk tanaman menggunakan handsprayer. Konsentrasinya disesuaikan dengan perlakuan yaitu $25 \%, 50 \%$ dan $75 \%$ untuk air kelapa, serta 60 ppm, 90 ppm, dan 120 ppm untuk BAP. Dosis yang digunakan adalah $15 \mathrm{ml}$. Aplikasi dilakukan pada 0 Minggu Setelah Perlakuan (MSP), 2 MSP, 4 MSP, 6 MSP, 8 MSP, 10 MSP. Waktu aplikasi zat pengatur tumbuh adalah pagi pukul 8.00 WIB.

Variabel pengamatan yang diuji adalah pertambahan tinggi tanaman, pertambahan jumlah daun, pertambahan jumlah tunas. Pengamatan dilakukan pada 0 sampai 12 MSP.

\section{Hasil dan Pembahasan}

Tinggi Tanaman. Penelitian ini menunjukkan bahwa tidak terdapat pengaruh konsentrasi zat pengatur tumbuh alami dan sintetik terhadap pertambahan tinggi tanaman teh (Tabel 1). Hal ini dapat terjadi karena tanaman teh telah mengalami pemangkasan sebelum aplikasi perlakuan air kelapa dan BAP. Menurut Setyamidjaja (2000) setelah dilakukan centering akan tumbuh cabang dari ketiak daun pada batang utama kearah lateral. Hal inilah yang menyebabkan pertumbuhan apikal cenderung lebih lambat dibandingkan pertumbuhan lateral.

Tumbuhnya cabang lateral dari ketiak daun terjadi karena pemangkasan menyebabkan transportasi auksin dari meristem apikal ke bagian bawah terhambat dan tidak berlangsung. Konsentrasi auksin di bagian ketiak daun akhirnya menjadi berkurang. Taiz dan Zeiger (1998) dalam Darmanti, dkk (2008) menjelaskan bahwa menurunnya kadar auksin di ketiak daun akan memacu pembentukan hormon sitokinin endogen yang berperan dalam pembentukan cabang lateral. Dalam hal ini sudah tidak terjadi dominansi apikal dalam tanaman.
Tabel 1. Pengaruh Konsentrasi Zat Pengatur Tumbuh Alami dan Sintetik terhadap Pertambahan Tinggi Tanaman Teh Klon GMB 7 setelah Centering.

\begin{tabular}{ccccccc}
\hline Perlakuan & \multicolumn{6}{c}{ Pertambahan Tinggi Tanaman (cm) } \\
\cline { 2 - 7 } & \multicolumn{6}{c}{ MSP } \\
\cline { 2 - 7 } & 2 & 4 & 6 & 8 & 10 & 12 \\
\hline A & 0,15 & 0,44 & 0,56 & 0,84 & 1,11 & 1,35 \\
B & 0,24 & 0,46 & 0,73 & 0,93 & 1,18 & 1,49 \\
C & 0,23 & 0,49 & 0,84 & 1,01 & 1,31 & 1,48 \\
D & 0,20 & 0,50 & 0,70 & 1,03 & 1,23 & 1,54 \\
E & 0,20 & 0,58 & 0,76 & 0,99 & 1,25 & 1,63 \\
F & 0,23 & 0,48 & 0,73 & 1,10 & 1,30 & 1,60 \\
G & 0,21 & 0,45 & 0,75 & 1,06 & 1,29 & 1,63 \\
\hline \hline
\end{tabular}

Keterangan: 1) Angka yang tidak diikuti oleh huruf pada kolom yang sama tidak berbeda nyata menurut uji $\mathrm{F}$.

2) MSP = Minggu Setelah Perlakuan

Jumlah Daun. Hasil analisis statistik pada Tabel 3 menunjukkan bahwa perlakuan G (BAP 120 ppm) memberikan hasil positif untuk pertambahan jumlah daun pada 4 MSP, begitu juga dengan perlakuan C (Air Kelapa 50\%), E (BAP 60 ppm) dan F (BAP 90 ppm).

Tabel 3. Pengaruh Konsentrasi Zat Pengatur Tumbuh Alami dan Sintetik terhadap Pertambahan Jumlah Daun Tanaman Teh Klon GMB 7 setelah Centering

Perlakuan Rata-rata Pertambahan Jumlah Daun

\begin{tabular}{ccccccc} 
& \multicolumn{5}{c}{ (helai) } \\
\cline { 2 - 7 } & \multicolumn{5}{c}{ MSP } \\
\cline { 2 - 7 } & 2 & 4 & 6 & 8 & 10 & 12 \\
\hline A & 1,63 & $5,75 a$ & 8,25 & 10,50 & 12,25 & 14,00 \\
B & 2,63 & $7,88 a b$ & 12,50 & 14,75 & 16,75 & 19,50 \\
C & 2,63 & $9,50 a b c$ & 12,88 & 15,25 & 17,63 & 19,75 \\
D & 2,75 & $8,75 a b$ & 12,75 & 14,88 & 15,50 & 16,63 \\
E & 3,88 & 11,00 bc & 15,38 & 17,00 & 17,75 & 20,50 \\
F & 5,38 & 10,13 bc & 13,00 & 15,25 & 16,75 & 21,00 \\
G & 5,50 & $15,13 \mathrm{c}$ & 20,13 & 22,63 & 23,25 & 26,50 \\
\hline
\end{tabular}

Keterangan: 1) Angka yang tidak diikuti oleh huruf pada kolom yang sama tidak berbeda nyata menurut Uji F. 2) Angka yang diikuti huruf yang berbeda pada kolom yang sama berbeda nyata menurut uji lanjut Duncan. 3) MSP = Minggu Setelah Perlakuan

BAP merupakan zat pengatur tumbuh yang memiliki kandungan senyawa nitrogen. Gardner (1991) mengemukakan bahwa dalam sitokinin terkandung senyawa nitrogen yang berperan untuk pengoptimalan proses sintetis asam-asam amino dan protein. Asam amino dan protein ini selanjutnya dimanfaatkan untuk 
pertumbuhan daun. Tekei (2001) dikutip Oksana (2012) mengungkapkan bahwa pertumbuhan sel pada tanaman dirangsang oleh sitokinin, selanjutnya sel-sel yang membelah tersebut akan berkembang menjadi tunas, cabang dan daun.

Hasil analisis pada 4 MSP menunjukkan bahwa perlakuan B (Air kelapa 25\%), C (Air kelapa 50\%) dan D (Air kelapa 75\%) tidak berbeda nyata dengan perlakuan A (Kontrol). Hal ini terjadi karena konsentrasi sitokinin yang terdapat dalam air kelapa lebih sedikit dibandingkan BAP menurut hasil analisis kandungan air kelapa yang telah dilakukan. Kandungan sitokinin pada air kelapa yaitu 8 ppm (air kelapa 25\%), 16 ppm (air kelapa 50\%) dan 24 ppm (air kelapa 75\%) (Balai Penelitian Tanaman Obat dan Rempah, 2017). Lebih rendahnya jumlah sitokinin eksogen yang berasal dari air kelapa ini menyebabkan sitokinin dalam tanaman belum dapat berperan besar dalam pertumbuhan tunas.

Jumlah Tunas. Hasil analisis statistik menunjukkan bahwa perlakuan E (BAP 60 ppm), F (BAP 90 ppm) dan G (BAP 120 ppm) berbeda nyata dengan perlakuan A ( Kontrol), B (Air Kelapa 25\%), C (Air Kelapa 50\%) dan D (Air Kelapa 75\%) pada 4, 6, dan 10 MSP (Tabel 4). Pada 12 MSP perlakuan G dan E memberikan hasil yang lebih baik dibandingkan perlakuan $\mathrm{A}, \mathrm{B}, \mathrm{C}, \mathrm{D}$, dan F.

Tabel 4. Pengaruh Konsentrasi Zat Pengatur Tumbuh Alami dan Sintetik terhadap Pertambahan Jumlah Tunas Tanaman Teh Klon GMB 7 setelah Centering

\begin{tabular}{ccccccc}
\hline \hline & \multicolumn{5}{c}{ Rata-rata Pertambahan Jumlah Tunas } \\
Perlakuan
\end{tabular}

Keterangan: 1) Angka yang tidak diikuti oleh huruf pada kolom yang sama tidak berbeda nyata menurut Uji F. 2) Angka yang diikuti huruf yang berbeda pada kolom yang sama berbeda nyata menurut uji lanjut Duncan. 3) MSP = Minggu Setelah Perlakuan

Perlakuan BAP 60, 90, dan 120 ppm diduga merupakan perlakuan yang tepat untuk pertumbuhan jumlah tunas tanaman teh karena dapat menambah jumlah sitokinin yang ada dalam tanaman sehingga membantu meningkatkan pertumbuhan tunas. Hal ini sesuai dengan pernyataan Panjaitan, dkk (2014), kinerja sitokinin eksogen (BAP) dan sitokinin endogen yang diproduksi akar dapat mendukung pertumbuhan tunas tanaman. Salisbury dan Ross (1992) menyatakan bahwa BAP dapat memicu pecahnya seludang tunas dan tumbuhnya mata tunas, selain itu BAP akan mencegah dominansi apikal sehingga pertumbuhan tunas samping tidak terhambat.

Seluruh perlakuan air kelapa menunjukkan pertambahan tunas lebih rendah dibadingkan perlakuan BAP. Hal ini terjadi karena konsentrasi sitokinin air kelapa yang berperan dalam pembentukan tunas lebih rendah dibandingkan BAP berdasarkan hasil analisis air kelapa. Penyebab lainnya dapat disebabkan karena adanya hormon auksin dan giberelin dalam air kelapa yang digunakan. Hormon auksin dan giberelin mendukung dominansi apikal sehingga pertumbuhan tunas lateral terhambat. Hormon giberelin mendukung pertumbuhan meristem apikal melalui stimulasi pemanjangan ruas (internode) (Gupta and Chakrabarty, 2013)

\section{Kesimpulan}

Zat pengatur tumbuh berupa BAP dengan konsentrasi $60 \mathrm{ppm}, 90 \mathrm{ppm}$ dan $120 \mathrm{ppm}$ memberikan hasil yang lebih baik dalam pertambahan jumlah daun (4 MSP), sementara BAP kosentrasi 60 ppm dan 120 ppm memberikan hasil positif terhadap pertambahan jumlah tunas $(4,6,10$ dan $12 \mathrm{MSP})$.

\section{Daftar Pustaka}

Badan Pusat Statistik. 2014. Statistik Teh di Indonesia. [Online]. Tersedia: https:// media.neliti.com/media/publications/487 11-ID-statistik-teh-indonesia-2014.pdf. Diakses pada 1 September 2016.

Darmanti, S., N. Setiari., dan T.D. Romawati. 2008. Perlakuan Defoliasi untuk Meningkatkan Pembentukan dan Pertumbuhan Cabang Lateral Jarak Pagar (Jathropa curcas L.). Buletin Agronomi dan Fisiologi 16(2): 13-16. [Online]. Tersedia: http://ejournal. undip.ac.id. Diakses pada 28 Mei 2017. 
Direktorat Perbenihan Perkebunan. 2014. Pengenalan dan identifikasi klon seri GMB. [Online]. Tersedia: http://ditjenbun. pertanian.go.id. Diakses 25 Agustus 2016.

Fahmi, Z.I. 2014. Direktorat Jenderal Pertanian. Kajian pengaruh auksin terhadap perkecambahan benih dan pertumbuhan tanaman. Tersedia: http://ditjenbun. pertanian.go.id. Diakses 30 Agustus 2016.

Gardner, F. P., R. B. Pearce, dan R. L. Mitchell. 1991. Physiology of Crop Plants. (Fisiologi Tanaman Budidaya, alih bahasa : Susilo dan Subiyanto). Jakarta: UI Press.

George, E.F., M.A. Hall., and G.J. De Klerk. 2008. Plant Propagation by Tissue Culture. Third edition. Springer. [Online]. Available: http:/ / citeseerx.ist.psu.edu. Diakses pada 5 September 2016.

Gupta, R., and S.K. Chakrabarty. 2013. Gibberellic Acid in Plant. [Online]. Available: www.ncbi.nlm.nih.gov. Diakses pada 5 Juni 2017.

Karjadi, A.K., dan Buchory, A. 2008. Pengaruh auksin dan sitokinin terhadap pertumbuhan dan perkembangan jaringan meristem kentang kultivar granola. J. Hort. 18(4): 380-4. Tersedia: http://hortikultura. litbang. pertanian.go.id. Diakses 25 Agustus 2016.

Oksana., E. Rahmadani., dan Syamsul. 2012. Peranan Berbagai Macam Media Tumbuh Bagi Pertumbuhan Stek Daun Jeruk J.C (Japanche citroen) dengan Beberapa Konsentrasi BAP. Jurnal Agroteknologi
2(2). [Online]. Tersedia: http://ejournal. uin-suska.ac.id. Diakses pada 27 Mei 2017.

Panjaitan, L.R.H., J. Ginting dan Haryati. 2014. Respons Pertumbuhan Berbagai Ukuran Diameter Batang Stek Bougenvil (Bougainvillea spectabilis Willd.) Terhadap Pemberian Zat Pengatur Tumbuh. Jurnal Online Agroteknologi 2 (4): 1384-1390. [Online]. Tersedia: http:// jurnal.usu.ac.id. Diakses pada 27 Mei 2017.

Salisbury, F.B., and C.W. Ross. 1992. Fisiologi Tumbuhan. Bandung: Institut Teknologi Bandung.

Setyamidjaja, D. 2000. Teh budidaya dan pengolahan pascapanen. Kanisius. Yogyakarta.

Sudjarmoko, B. 2014. Perkembangan teh Indonesia di pasar domestik dan pasar internasional. [Online]. Tersedia: balittri. litbang.pertanian.go.id. Diakses 24 Agustus 2016.

Syakir, M., D.S. Effendi., M. Yusron., dan Wiratno. 2010. Budidaya dan pascapanen teh. Pusat penelitian dan pengembangan perkebunan. [Online]. Tersedia: http:// perkebunan.litbang.pertanian.go.id. Diakses pada 25 Agustus 2016.

Yong, J.W.H., L. Ge., Y.F. Ng., and S.N. Tan. 2009. The chemical composition and biological properties of coconut (Cocos nucifera L.) water. [Online]. Available: http://www.mdpi.com. Diakses pada 8 September 2016. 